\title{
Festivals, Weddings and Ceremonies of the Old Uzbek Literary Language in the XVI Century Writings
}

\author{
Azamat Primov, Munira Rakhimova \\ Department of Uzbek Linguistic, Faculty of Philology, Urgench State University, Urgench City, Uzbekistan \\ Email address: \\ goodluck_0714@mail.ru (A. Primov), munira_0801@mail.ru (M. Rakhimova)

\section{To cite this article:} \\ Azamat Primov, Munira Rakhimova. Festivals, Weddings and Ceremonies of the Old Uzbek Literary Language in the XVI Century Writings. \\ International Journal of Secondary Education. Vol. 6, No. 1, 2018, pp. 5-7. doi: 10.11648/j.ijsedu.20180601.12
}

Received: December 19, 2017; Accepted: January 15, 2018; Published: January 31, 2018

\begin{abstract}
This article presents the actual materials in which the lexical and semantic features of the words expressing holidays, wedding and other events are given, translated in 1519 by Muhammad Ali ibn Darves Alm al-Bukhari from the works of "Boburname" by Babur and "Zafarnoma" by Sharafuddin Ali Yazdiyya two works that were created in the 16th century in Old Uzbek literary language and could incorporate the language of that time, as well as their relation to the modern literary Uzbek language.
\end{abstract}

Keywords: Heortonims of the Uzbek Language, Heortonyms, Holiday, Wedding, Ceremony, Funeral, HAyit

\section{Introduction}

The processes which took place in socio-political, economical, cultural life of Mavarannahr are reflected in the language, namely, in lexicon. The lexicon of such works written in Uzbek literary language of XV-XVIII as "Shayboninoma" by Mukhammad Solikh, lyrics of "Boburnoma" by Bobur, "Sabotul ojizin" by Sufi Olloyor, "Shajarayi turk" by Abulgazi Bakhodirkhan incorporate the development of that period [1]. Moreover, there is a work which also incorporates the old uzbek language of the XVI century, which is Sharafuddin Ali's called "Sayahatnama". It was completed in 848 pertaining to the Hijra calendar (14241425 A. D.) in Persian. The Uzbek version of this book translated by Mohammad Ali ibn Darvesh Ali al-Buhoriy in 1519 due to the decree of Kuchkinchikhon of Shaybonids play a significant role [2]. H. Dadaboyev, in his article dedicated to this book illustrates that it has a wide range of vocabulary and it is an important issue to analyze it from linguistic point of view.

There was a monographic research according to telexes of "Baburnama" [3]. The attempts to investigating of the notions that express the names of holidays, celebrations and festivals in that book separately do not repeat the researches that were done till today.

Bobur's "Boburnama" and the translation of "Zafarnama" ("The song of victory") mentioned above are considered as magnificent works of classical prose and the main resources of learning the linguistic features at the end of XV century and at the beginning of XVI century. It is apparently known that a great amount of heortonyms, the names of holidays, ceremonies were used in both of the books. For instance, Navruz, Iyd al-fitr, Ramadan and interesting information how to celebrate them as well.

\section{Method}

In the basis books to this article you can encounter a lot the heortonyms related to the Islam religion, such as Ruza khayiti, Kurban khayiti.

Obviously, there are two main holidays in Islam religion, one of them is bigger Kurban hayit (in Arabic "Iyd al-kabir", "Iyd al-adha") was celebrated for seven days, now it is celebrated for three days on 10-13 days of zulhijja (the twelfth month of the Islamic lunar calendar, in which the Hajj takes place) month, and smaller one Ruza hayit (in Arabic "Iyd al-sagir", "Iyd al-fitr") is also celebrated for three days on the 1-3 days of shaval month.

We can observe that names of current holidays are sometimes given in style as Iyd, sometimes the name of Ruza is given as Iyd-fitr.

There has been called"iyd hiloli" word combination in the beginning of Ramadan. "Хилол” means "new moon".

The word "iydgoh" has been formed by adding goh suffix 
to the word "iyd" and gives the meaning of the place where festivals are celebrated.

The word "iyd" has been appeared as a heortonym. Now Iyd can not be used as an anthroponomy, but there are other varieties such as: Hayit, Hayitjon, Hayitboy, Hayitgul; Ruza, Ruziboy, Urozgul, Urozmat; Kurbon, Kurbonoy.

The words festive, wedding and wedding ceremony are mostly used. Zifaf was used luxury wedding party in the translation of "Zafarname" (song of the victory). This word can not be found in "Boburname", but was used in A. Navoi's works [4]. Present days the word "zifaf" means "wedding", "wedding ceremony" in the arab language [5]. In modern uzbek language it is considered archaism.

In the extract besides the terms that are related to wedding ceremony, the customs of Amir Temur period which describes spreading of money over the couples heads beatifully described. With the help of this information we can clearly know that the custom has a long history and today as well as money and sweets are spread over.

The term "sur" has several homonyms: 1 . horn 2 . wedding, party, 3. fortess 4. nicname [6]. The meaning wedding and party can not be found in uzbek explanatory dictionaries. In Navoi's works the term "sur" that have the meaning wedding, party, happines was used.

In Navoi's works "sur" was used as wedding and "surur" used as merriment, happiness [7]. In "Zafarname" the term "sur" can not be found, but the term "surur" was used as happiness, merry besides it had the meaning wedding, merriment. The term "surur" original arabic word and means 'merriment' and 'happiness' [8]. Wedding and merriment can be a partial synonyms. In general, the terms "sur"and "surur" are both give the same meaning although the former is turkish word, the latter is arabic one. The term "maraka" in analyizing sources described as: 1. place where people gather; 2. battle field. The term "maraka" is an arabic word originated from the verb "marakatun", in uzbek language it means "to battle"[9].

\section{Result}

This word in Uzbek explanatory dictionary, expressing the following meanings:

1) the collection of funeral ceremonies and each one;

2) wedding rituals and ceremonies relating to weddings;

3) battle and battle field is indicated as homonym;

And also the connotational meaning of the word "ma'raka" (memorial service) expressing "actions having political and household significance which are held massively, company) is shown in this dictionary. It can be clearly seen that, the following meanings of the word "ma'raka" (memorial service), 1) the collection of funeral ceremonies and each one, 2) wedding rituals and ceremonies relating to weddings were formed after XVI century.

In "Boburnoma" and "Zafarnama" ("The song of victory") instead of the words "hospitability" and "party" the words osh, osh tortmoq, osh-suv and the word combination oshu ob were used. Originally being Persian word "ovqat (yovg'on, shorva xo'rda)+suv having the meaning "meal + water" was used as heortonym at that period: Mirshoxbek served oshu ob". In "Zafarnama" there was no the word combination oshu ob used. The second part of it being Uzbek word, was used as pair osh-suv.

In our modern language, the word combination of yurtga osh bermoq is used to mean to organize party for people cooking pilav in a big pot in wedding and other ceremonies. Funeral rituals also are expressed with the word osh. And also in the structure of the words qiz oshi, xotin oshi, maslahat oshi which are held in some cases there is the word osh.

\section{Discussion}

In "Boburnoma" Persian word chashn also means "party", "feast", "wedding". Navoi, also, in his literary works, used this word as "festive meeting" and "party". In "Xazoyinulmaoniy" being used as the second part of compound words, the component chash means "drinker", "taster", "doer.

Май ичра аксингаро софчашға айшу нажот,

Қадахда нашъанг ила дурдикашға завқу сурур [10].

In Russian and also in our language the words chasha and chashka expressing "bowl", "goblet", "cup", from our point of views, are derived from the word chash which means "drinker", "taster" in Persian. We consider that Persian chashma is also the component of this word.

In "Boburnoma", the word choshnigir was used in order to mean "food controller", "taster". In Modern Uzbek language the words chashnachilik, chashnagirlik are used to identify the quality of raw products such as grape, wine, food, or plants by tasting, smelling, seeing and hearing. Generally, we cannot say that the words chashn (feast) choshn (taste) are paronyms. From our perspectives, with the meaning of taste and flavor, chashn choshn had acquired connotative meaning expressing feast, party.

In "Boburnoma", the person who calls rain with the help of a special stone called yadachi - "rain-caller": Ақраб булгоч, ядачилара буюрурбизким, яда құлвайлар. The noun "yadachilig" was used in the work: Қушчилигни ва ядачиливни хуам билур эди. There's some information about the stone: "Jada" and its use in the ceremony of rain calling in the past of Uzbek nation. Majority of historicalethnographic literatures inform about the stones called "yada", "jada", "sata", "d'ada" which have the magical power to change the weather. All of these terms refer to different forms of the word "yada" and its national variations. V. V. Radlov explains one meaning of the word "jada" as "rainmaker stone" [10]. S. E. Malov exclaims that the word "d'ada" (altarism, magic) is derived from the Persian word "d'ata" (altar, magician) [11], but in another source it is said that this word is originated from the old Turkish word "jat" which expressed the meaning "magic to attract the rain and the wind" [12]. It is obvious that there's connection between the word "jodu" (witchcraft) in "jodugar" (witch) and the word "yada". 


\section{Conclusion}

Generally, in two great masterships "Boburnoma" and Sharafiddin Ali Yazdiy`s "Zafarnama"("The song of victory") were written at the beginning of 16 th century in old Uzbek and fully embodied that period's language in itself, by looking through their interpretation in Uzbek, their lexis, analyzing and categorizing terms and proper nouns that expresses ceremonies, celebrations, weddings, we may see that both of them are rich in lexis, and they are unrepeatable, though they were created at the same period there were some similar and different features between them, also in these works different words that appeared by the influence of social processes are used and factors like the narration style of the authors, vocabulary had great importance.

Applying, researching and collecting Uzbek heortonym different writings created in the development of Uzbek language inform about festivals and different celebrations and much information about them.

\section{References}

[1] Dadaboyev H, Hamidov Z, Holmonova Z. The history of the lexicology of the Uzbek Literary. Tashkent, Science, 2007.

[2] Sharafuddin Ali Yazdiy. Zafarnoma. (Ashraf Ahmad, Haydarbek Bobobekov prepared for publishing) Toshkent, Sharq, 1997. p 384 (this book can be given as an abbreviation with its page in the article).
[3] Xolmonova Z. "Boburname" lexis. Tashkent, Science, 2007. p 176.

[4] Explanatory dictionary of Alisher Navoi works. A four volume work. 1st volume. Toshkent: Science, 1983, p 150.

[5] Mahmudov N. and others. Uzbek-Russian-English-FrenchArabic Dictionary. Toshkent, Spitituality, 2012. p. 150.

[6] For "Boburname"short explanatory dictionary. Andijon, Andijon publisher-press, A 2008. p. 157.

[7] Explanatory dictionary of Alisher Navoi works. A four volume work. 3rd volume. Tashkent. Science, 1984. p 130.

[8] Uzbek explanatory dictionary. A three volume work. Natinal Uzbek Encyclopedia, Tashkent. 2007. p. 596.

[9] Rahmatullayev Sh. Uzbek etymology dictionary. A two volume work. Tashkent: University, 2003.

[10] The dictionary of Alisher Navoi's works. Four volumes. Volume 3. -Tashkent: Fan, 1984.

[11] Radlov V. V. Experience of the dictionary of the Turkic dialects. T. III, I. - Spb. - from. 367.

[12] Malov S. E. Shaman stone "poison" in the Turks of Western China. - SE, 1947. №1.- p. 154; Monuments of ancient Turkic writing. - M.-L., 1951. - p. 444.

[13] Ancient Turkic dictionary. - L., 1969. - p. 247. 